Al-Adzka: Jurnal Ilmiah Pendidikan Guru Madrasah Ibtidaiyah

p-ISSN: 2088-9801 I e-ISSN: 2597-937X

Vol. 10, No. 2 (Desember 2020), Ha1. 88 - 97

\title{
METODE PROBLEM BASED LEARNING UNTUK MENGKLASIFIKASIKAN ARGUMEN MAHASISWA PGSD TERHADAP MASALAH
}

\author{
Mohammad Archi Maulyda, Dyah Indraswati, Lalu Hamdian Affandi, Nursaptini, Fitri Puji \\ Astria \\ Program Studi Pendidikan Guru Sekolah Dasar, Universitas Mataram \\ Nusa Tenggara Barat, Indonesia \\ Website: \\ https://jurnal.uinantasari.ac.id/index.php/adzka
}

Received: 30 Juni 2020; Accepted: 22 Oktober 2020; Published: 21 Desember 2020

DOI: $10.18952 /$ aladzkapgmi.v10i2.3775

\begin{abstract}
The purpose in this study is to classify the types of arguments given by students when solving problems. The research method used is a qualitative approach with a descriptive. The research subjects were 50 students who had conducted lectures using the PBL method. The results showed that student arguments were divided into 3 types of categories namely, (1) True-False Arguments; (2) Good-Bad Argument; and (3) Policy Document. The type of argument most often used by students is True-False. An argument in which the subjects in this group tend to give statements to justify their opinions or refute the opinions of others. While the subject in the Good-Bad Argument group tends to see the argument based on the usefulness and implementation of the statement in real terms. For the type of argument Policy Arguments in this group tend use the data Act or government policy as the basis for his argument.
\end{abstract}

Key Words: PBL; argument; problems

\begin{abstract}
ABSTRAK
Tujuan dalam penelitian ini adalah mengklasifikasikan jenis-jenis argument yang diberikan mahasiswa ketika menyelesaikan masalah. Metode penelitian yang gunakan adalah pendekatan kualitatif dengan pendekatan deskriptif. Subjek penelitian adalah 50 mahasiswa PGSD Universitas Mataram yang telah melaksanakan perkuliahan dengan metode PBL. Hasil penelitian menunjukkan bahwa argument mahasiswa terbagi menjadi 3 jenis kategori yakni, (1) True-False Argument; (2) Good-Bad Argument; dan (3) PolicyArgument. Jenis argument yang paling sering digunakan mahasiswa adalah True-False Argumen dimana subjek dalam kelompok ini cenderung memberikan pernyataan untuk membenarkan pendapatnya atau menyanggah pendapat orang lain. Sedangakan subjek dalam kelompok Good-Bad Argument cenderung melihat argument berdasarkan kebermanfaatan dan implementasi pernyataanya secara nyata. Untuk jenis argument Policy Argument subjek dalam kelompok ini cenderung tidak menggunakan teori-teori individual (personal) namun menggunakan data Undang-Undang atau kebijakan pemerintah sebagai landasan argumenya.
\end{abstract}

Kata Kunci: PBL; argumen; masalah 


\section{PENDAHULUAN}

Kehidupan manusia tidak pernah lepas dari masalah. Masalah merupakan suatu aspek kehidupan yang melekat dalam diri manusia (Walton, 2018). Karena itu secara insing, manusia selalu memiliki kemampuan untuk mencari solusi dari masalah-masalah yang dihadapinya (Gustina \& Miaz, 2019). Menurut Anugrahana (2013) salah satu cara yang digunakan manusia untuk mencari solusi dari suatu masalah adalah berdiskusi. Sebagai mahluk social, manusia tentu memiliki kecenderungan untuk menyelesaikan masalah bersama-sama (komunal). Dalam bekerjasama ini lah argument dari seseorang akan menentukan arah solusi yang dihasilkan (Boell \& Hovorka, 2019). Menurut Siegel (2015) argument merupakan pendapat dan gagasan seseorang yang disampaikan secara dialog atau verbal. Argumen juga dapat menjadi gambaran pola pikir dan sifat seseorang. Menurut Eemeren, Frans, \& Garssen (2010) setiap pikiran (otak) memilki ruas-ruas pembentukan gagasan yang berbeda-beda. Hal ini dipengaruhi oleh pengalaman, informasi, dan fakta-fakta yang tersimpan di otak seseorang. Ide atau gagasan yang dipikirkan kemudian dapat disampaikan kepada orang lain dalam bentuk argument (Osborne, 2017);(M. A. Maulyda et al., 2020).

Salah satu permasalahan pendidikan adalah proses pembelajaran terlalu berorientasi pada penguasaan teori dan hafalan sehingga penalaran dan kreativitas siswa kurang berkembang (Sutisna et al., 2019). Ide-ide kreatif sangat dibutuhkan dalam menyelesaikan berbagai permasalahan dan tantangan kedepan (Widodo et al., 2020). Pendidikan abad 21 harus mampu membekali siswa dengan 4 kompetensi antara lain: communication, collaboration, critical thinking and problem solving, serta creativity and innovation (Indraswati et al., 2020). Dalam dunia pendidikan, keberadaan argument dan pemecahan masalah sudah banyak diterapkan (Ijirana \& Nadjamuddin, 2019). Kemampuan pemecahan masalah merupakan kemampuan yang sedang gencar dikembangkan agar seseorang dapat menyelesaiakan masalah-masalah yang dihadapi dalam kehidupan sehari-hari dengan baik (Hendarto \& Adi, 2019);(Santoso et al., 2020). Dalam pelaksanaan pembelajaran diperlukan model yang mampu memperkuat pendekatan ilmiah (scientific) agar siswa dapat berpikir logis, berpikir kritis, dan dapat memecahkan masalah dengan kreatif, inovatif, dan bersikap terbuka (Indraswati, 2018). Dalam Kurikulum Pendidikan terbaru (K-13), salah satu model pembelajaran yang dianjurkan adalah Problem Based Learning (PBL). Dalam model pembelajaran PBL ini siswa dituntut untuk mengkonstruksi sebuah konsep dari suatu masalah (Nofitasari et al., 2019). Hal ini juga merupakan salah satu bentuk pembiasaan bagi siswa untuk mencari solusi-solusi dalam menyelesaikan masalah dalam kehidupan seharihari.

Dalam model pembelajran PBL, salah satu kunci keberhasilan model ini adalah argument dari siswa. Hal ini dikarenakan model ini cenderung mengarahkan siswa untuk berdiskusi terhadap masalah yang diberikan (Anugrahana, 2013). Tidak hanya untuk siswa, model PBL ini juga sering diterapkan pada mahasiswa pada jenjang perguruan tinggi. Mahasiswa harus dilatih dalam berdiskusi dan menyampaikan pendapat untuk mencari solusi terhadap masalah yang diberikan (Maulyda, Hidayati, Erfan, Umar, \& Sutisna, 2020). Karena masingmasing mahasiswa ini memiliki kemampuan dan pola pikir yang berbeda-beda, maka argumentasi yang disampaikan juga menjadi berbeda. Terdapat beberapa penelitian yang menganalisis argument-argumen yang disampaikan seseorang. Berdasarkan hasil penelitian Savchuk (2017) dan Gavgani, Hazrati, \& Ghojazadeh (2015) subjek penelitian yang berjenis kelamin laki-laki cenderung memiliki argument yang lebih teoritis dan kuat dibandingkan dengan subjek penelitian yang berjenis kelamin perempuan. Penilitian lain dari Mazilu (2017) menyebutkan bahwa proses argument yang diberikan oleh subjek yang berusia 18-23 tahun 
merupakan argument dengan kualitas yang baik. Sedangkan penelitian Sunaringtyas, Asikin, \& Junaedi (2017) dan Ijirana \& Nadjamuddin (2019) menyebutkan bahwa argument yang baik dipengaruhi oleh kemampuan seseorang dalam mengkonstruksi kalimat. Sehingga kemampuan verbal seseorang merupakan kunci dalam penyampaian argument seseorang.

Dalam penelitian ini, secara spesifik peneliti ingin mengklasifikasikan jenis-jenis argument yang disampaikan mahasiswa ketika diberikan masalah. Penelitian-penelitian sebelumnya sudah menggambarkan proses dan factor yang mungkin membedakan argument seseorang. Namun belum ada penelitian yang secara rinci mengklasifikasikan jenis-jenis argument yang diberikan oleh mahasiswa. Peneliti berharap penelitian ini dapat menjadi tambahan khasanah wawasan pengetahuan terkait jenis-jenis argument yang dapat ditemukan pada mahasiswa.

\section{METODE PENELITIAN}

Pendekatan penelitian yang digunakan oleh peneliti adalah pendekatan kualitatif. Menurut Creswell (2012) penelitian kualitataif merupakan gambaran fenomena-fenomena yang terjadi dalam kehidupan yang disampaikan secara factual. Subjek dalam penelitian ini adalah 50 mahasiswa semester IV yang telah mengikuti perkuliahan dengan metode PBL. Prosedur penelitian dilakukan dengan memberikan 2 problematika kepada 50 subjek penelitian.

Tahap awal adalah pengelompokkan 50 subjek penelitian dalam 10 kelompok dimana setiap kelompok berisi 5 mahasiswa. Setelah itu keseluruhan kelompol akan diberikan problematika sebagai bahan diskusi. Problematika yang diberikan merupakan masalah terbuka yang diharapkan dapat menggali ide-ide dan gagasan subjek secara luas. Setiap subjek penelitian akan diberikan waktu selama 30 menit untuk berdiskusi dalam kelompoknya. Setelah itu, subjek penelitian diberikan waktu 30 menit lagi untuk menuliskan argument-argumen yang dia hasilkan sebagai dasar untuk pengajuan solusi terhadap masalah. Setelah problematika pertama selesai, subjek penelitian diberikan waktu selama 30 menit untuk beristirahat sebelum menyelesaiakan problematika kedua dengan cara dan waktu yang sama.

\section{HASIL PENELITIAN DAN PEMBAHASAN}

\section{A. Hasil Penelitian}

Berdasarkan analisis yang dilakukan kepada hasil argument 50 subjek penelitian, peneliti menemukan terdapat 3 kategori jenis argument. Kategori pertama merupakan argument True-False Argument, Good-Bad Argument, dan Policy Argument. Berikut data tabulasi ketiga ketegori jenis argument subjek: 


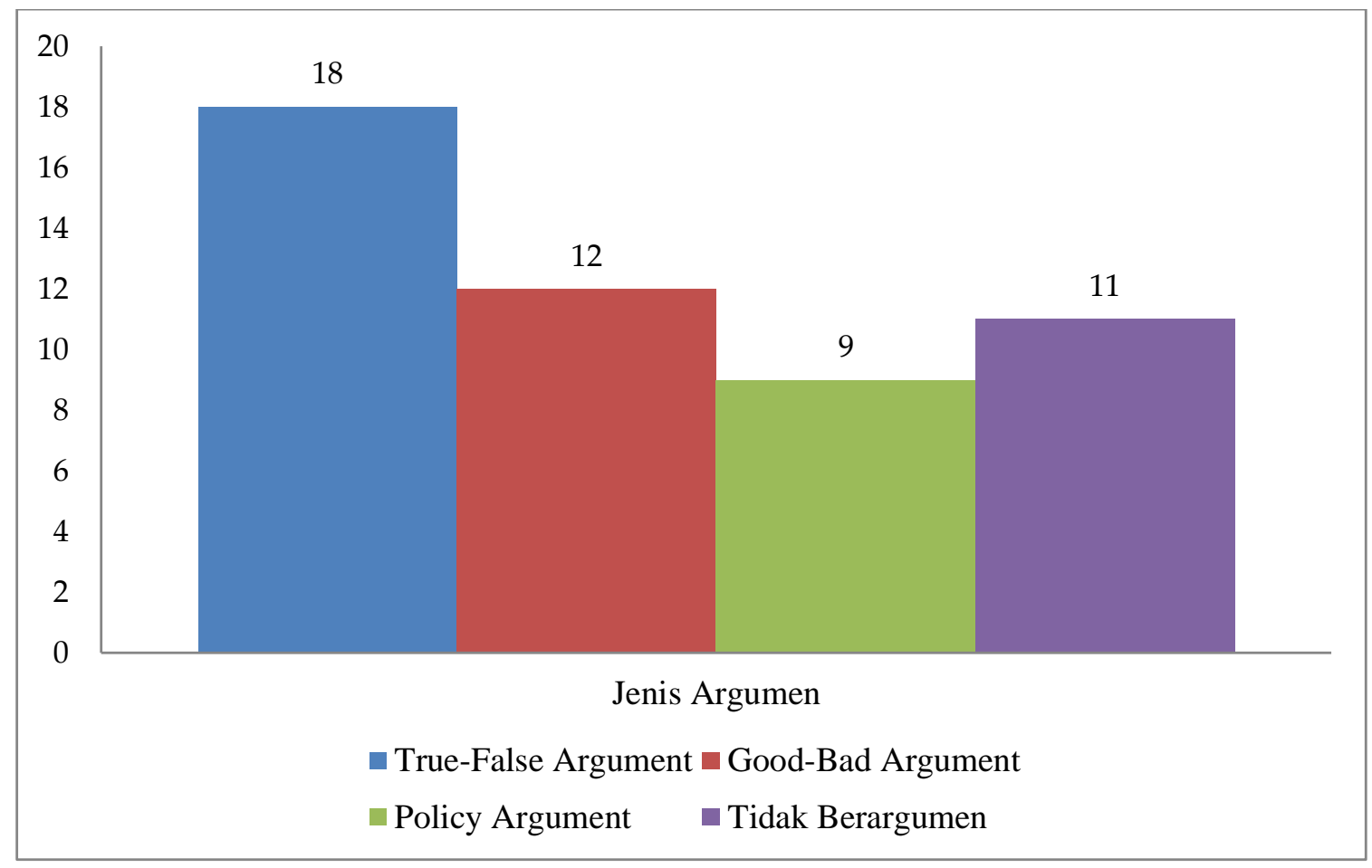

\section{Gambar 1. Tabulasi Jenis Argument Subjek Penelitian}

Berdasarkan hasil penelitian, sebagian besar mahasiswa menggunakan argument TrueFalse Argument untuk menyampaikan solusinya dalam permasalahan. Jumlah mahasiswa yang memilih menggunakan argument ini adalah 18 subjek. Sedangkan mahasiswa yang memmilih argument Good-Bad Argument adalah 12 subjek. Kategori selanjutnya adalah Policy Argument, dimana jumlah mahasiswa yang memilih argument ini paling sedikit yakni 9 orang. Selain itu juga terdapat 11 argument mahasiswa yang tidak dapat dikategorikan. Hal ini dikarenakan mahasiswa tidak memberikan argument yang lengkap argumenya tidak sesuai (tidak relevan) dengan masalah yang diberikan.

\section{B. Pembahasan}

Metode pembelajaran PBL yang diterapkan dalam perkuliahan sangat tepat untuk menggali ide-ide mahasiswa dalam berargumen. Mahasiswa yang diberikan masalah cenderung memiliki keinginan untuk menyampaikan ide-ide dan solusinya untuk menyelesaikan masalah tersebut. Berdasarkan hasil penilitian N, Reed, \& Macagno (2013) usia 18-21 tahun merupakan usia-usia yang sangat ideal untuk membentuk pola pikir seseorang. Hal ini didukung oleh pernyataan ahli psikologi Boell \& Hovorka (2019) yang menyatakan bahwa rasa penarasan, pemberontakan, dan berpikir kritis merupakan gabungan yang tepat untuk belajar menemukan kemungkinan-kemungkinan dan solusi dalam sebuah permasalahan atau kasus. Karena itu model pembelajaran PBL yang diterapkan kepada mahasiswa sangat efektif untuk melatih kemampuan pemecahan masalah mahasiswa (Santoso et al., 2020).

Salah satu bentuk penyampaian ide gagasan yang dilakukan oleh mahasiswa adalah berdiskusi. Dalam aspek diskusi, konstruksi argument sangatlah penting untuk diperhatikan (Siegel, 1995). Berdasarkan hasil pengamatan pada hasil penelitian, mahasiswa cenderung antusias dalam memberikan argument. Meskipun terdapat beberapa mahasiswa yang tidak 
memberikan argument yang jelas dan pada akhirnya tidak teridentifikasi. Namun, sebagian besar argument yang diberikan mahasiswa cukup baik dan lengkap. Hal ini sejalan dengan hasil penelitian Maulyda \& Hidayati (2019) dan Myklebust \& Hoisaeter (2018) dimana mahasiswa memilki kecenderungan lebih senang menyampaikan ide dan gagasan lewat verbal (lisan) daripada lewat tulisan. Berdasarkan hasil penelitian yang dilakukan, jenis argument yang diberikan mahasiswa terbagi menjadi 3 kategori sebagai berikut:

\section{True-False Argument}

Kategori pertama adalah kelompok subjek penelitian yang argumenya berstruktur pada kebenaran dan kesalahan pernyataan tersebut. Subjek dalam kelompok ini cenderung menggunakan teori-teori yang sudah ada dan valid untuk menyatakan kebenaran pernyataanya. Selain itu subjek dalam kelompok ini juga menggunakan teori yang sudah ada untuk menyanggah pernyataan atau argument orang lain. Menurut hasil penelitian Gustina \& Miaz (2019) pola argumentasi yang baik adalah adanya dukungan-dukungan teoritis dalam pernyataanya. Keberadaan penguat teori yang sudah pasti benar (valid) dapat menjadi penentu kebenaran dan kesalahan penyataan kita. Dalam perspektif fungsinya, salah satu fungsi dari argumentasi adalah alat untuk menyampaikan sebuah kebenaran atau menyampaikan kesalahan orang lain (Walton, 2018). Salah satu potongan argument yang disampaikan subjek dalam kelompok ini adalah sebagai berikut:

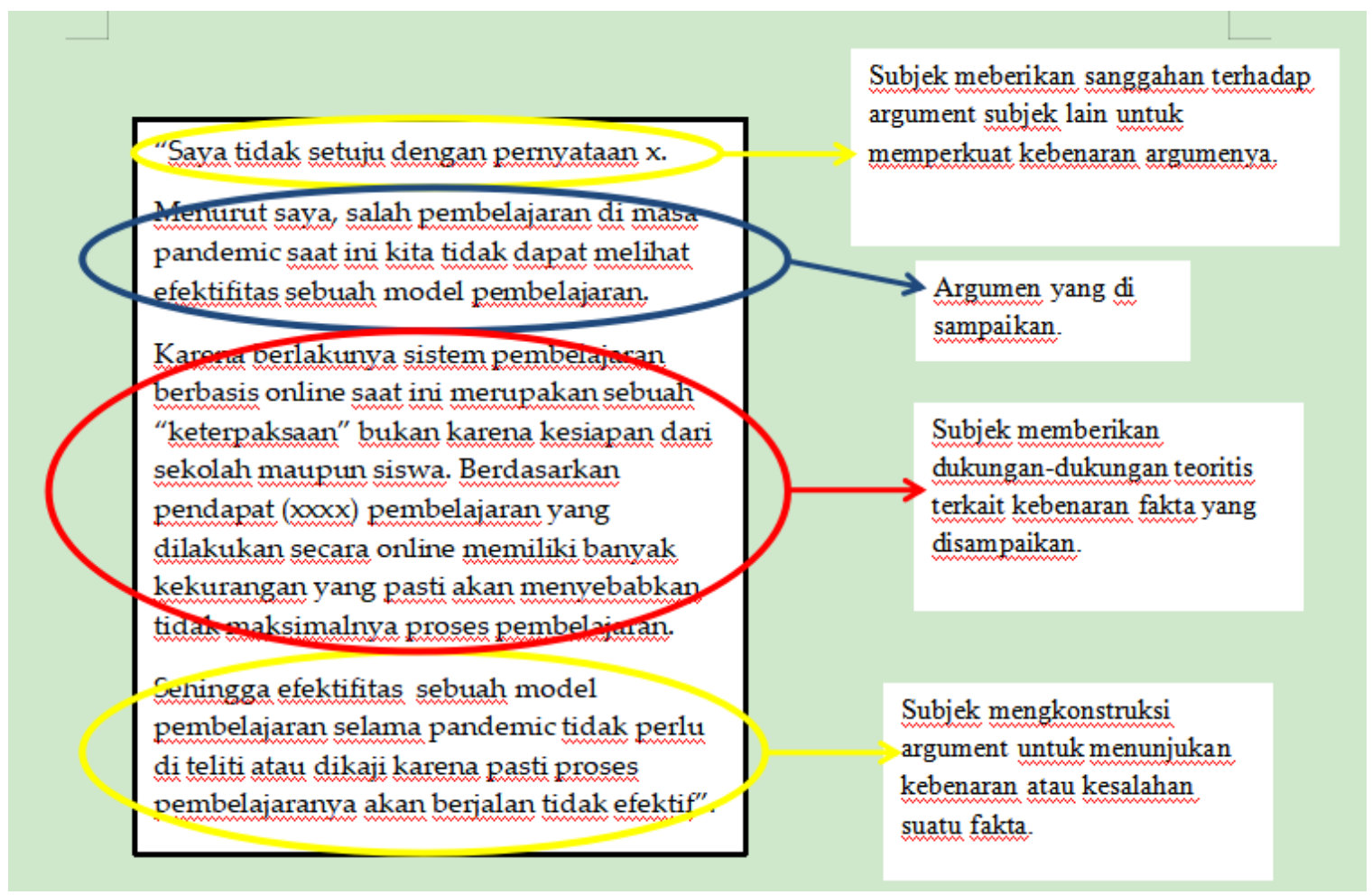

Gambar 2. Struktur Argumentasi Kategori True-False Argument

Dalam proses pembelajaran Problem Based Learning (PBL) salah satu aspek yang diutamakan adalah bekerjasama dan berkolaborasi (Davidson \& Major, 2014). Hal ini dikarenakan pembelajaran berbasis PBL biasanya akan dipasangkan dengan diskusi kelompok. Terkait dengan hal tersebut subjek yang berkategori argumentasi True-False biasanya akan 
memiliki argumentasi yang lebih objektif. Karena itu, apabila dalam sebuah kelompok banyak yang memiliki argumentasi bertipe ini, akan membuat diskusi kelompok menjadi hidup dan berbobot. Hal ini dikarenakan kecenderungan adanya dukungan teoritis dari subjek dalam diskusi kelompok. Masalah yang diberikan dalam pembelajaran yang didiskusikan dalam kategori argumentasi ini akan dapat dianalisis secara mendalam.

\section{Good-Bad Argument}

Kategori selanjutnya adalah kelompok subjek penelitian yang menggunakan argumentasi Good-Bad Argument. Subjek penelitian dalam kelompok ini cenderung menggunakan argumenya untuk melihat implementasi dan kebermanfaatan teori yang disampaikan. Subjek dalam kelompok ini menggunakan argumenya untuk mengkaji penerapan teori yang disampaikan dalam sebuah kejadian atau baik atau tidaknya implementasi argumenya. Menurut Hendarto \& Adi (2019) sangat jarang ada seseorang yang berpikir tentang penerapan pernyataanya. Kebanyakan arah diskusi berjalan hanya untuk penentuan kebenaran dan kesalahan suatu pernyataan. Sedangkan implementasi dari penyataan yang dihasilkan jarang sekali dikaji oleh seseorang (Eemeren et al., 2010). Namun dengan adanya 12 subjek yang mnggunakan argumentasi ini maka dapat dikatakan bahwa subjek memiliki kemampuan berpikir yang cukup kritis dalam memandang sebuah permasalahan (Anugrahana, 2013). Untuk memperjelas pola argument dalam kelompok Good-Bad Argument dapat diperhatikan gambar 3 berikut:

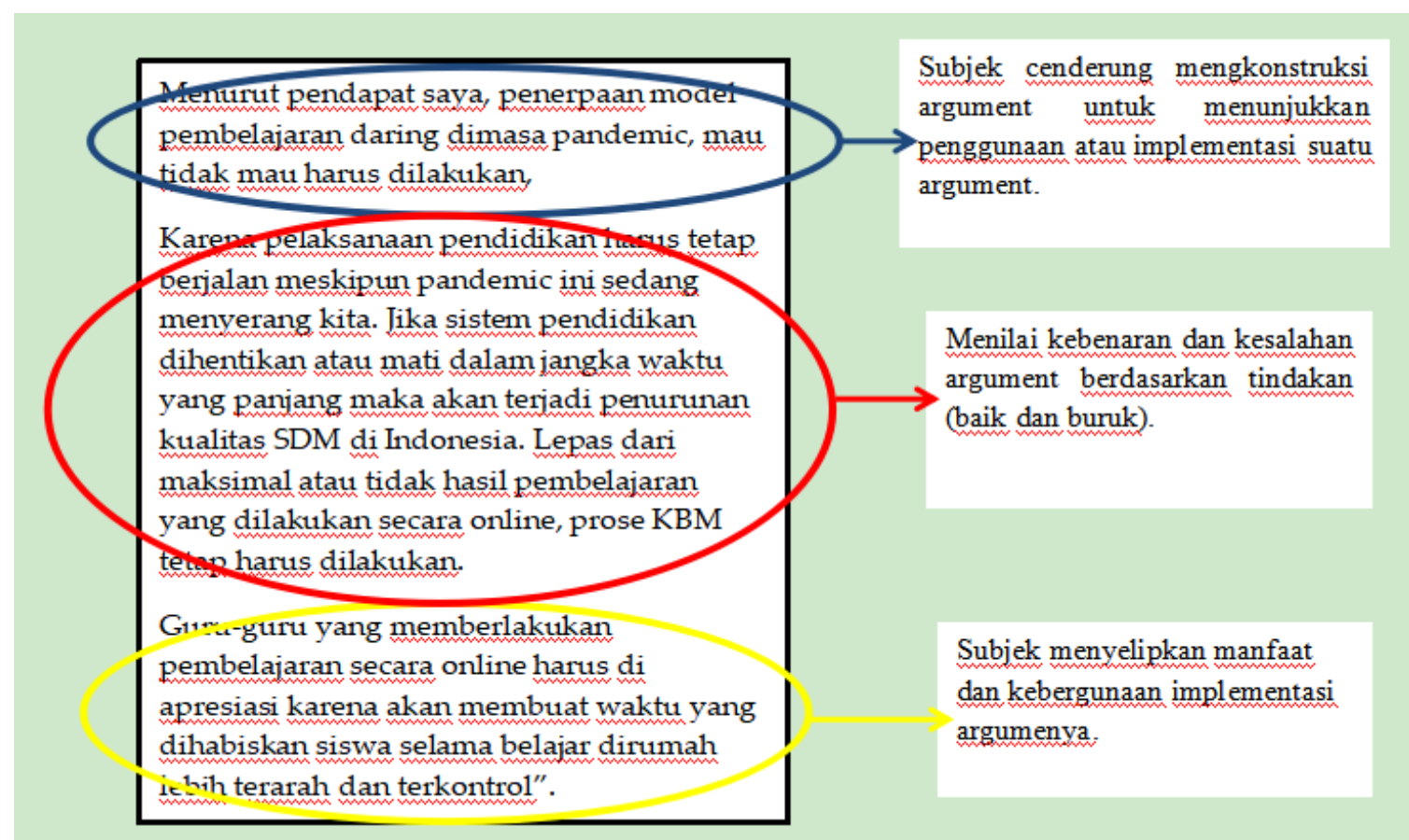

Gambar 3. Struktur Argumentasi Kategori Good-Bad Argument

Salah satu sintaks dalam pembelajaran PBL adalah pemberian masalah. Tujuan dari sintaksi ini adalah melatih siswa dalam menyelesaikan masalah-masalah yang nantinya akan ditemui (Dolmans et al., 2016). Dalam aspek argumentasi Good-Bad, argumentasi yang diberikan oleh siswa lebih bersifat subjektif. Menurut Schunk (2012) secara terminologis, baik dan buruk adalah perspektif semu yang dimiliki setiap manusia. Karena Setiap manusia akan memiliki informasi, pengalaman, dan data-data yang berbeda dalam otaknya masing-masing. Sehingga 
pengolahan masalah yang dilakukan oleh setiap manusia akan berbeda-beda. Dalam pembelajaran PBL, subjek yang memiliki argumentasi bertipe ini akan mengalami kesulitan dalam mempertahankan argumentasinya. Seperti yang sudah dijelaskan, hal ini dikarenakan subjektifitas argument yang sangat kuat. Setiap individu dalam anggota kelompok sangat mungkin memiliki perspektif yang berbeda dalam menentukan nilai baik dan buruk terhadap suatu masalah.

\section{Policy Argument}

Kategori terakhir adalaha kelompok subjek penelitian yang menggunakan argumentasi Policy Argument. Argumen yang dikonstruksi oleh subjek penelitian dalam kelompok ini cenderung menggunakan landasan-landasan peraturan pemerintah atai Undang-Undang. Subjek dalam kelompok ini berargumen berdasarkan kebijakan yang dikeluarkan oleh pemerintah. Subjek dalam kelompok ini jarang menggunakan teori-teori atau data dari individu personal (artikel, buku, atau prosiding). Namun subjek penelitian lebih sering menggunakan UU atau bentuk peraturan pemerintah lainya untuk memperkuat argumentasi yang disampaikan. Karena berlandaskan peraturan yang dibuat pemerintah, implementasi argument yang disampaikan cenderung sempit atau hanya berlaku pada wilayah-wilayah yang berlaku kebijakanya. Untuk memperjelas pola argumentasi subjek pada kelompok ini, dapat dilihat dalam gambar 4 berikut:

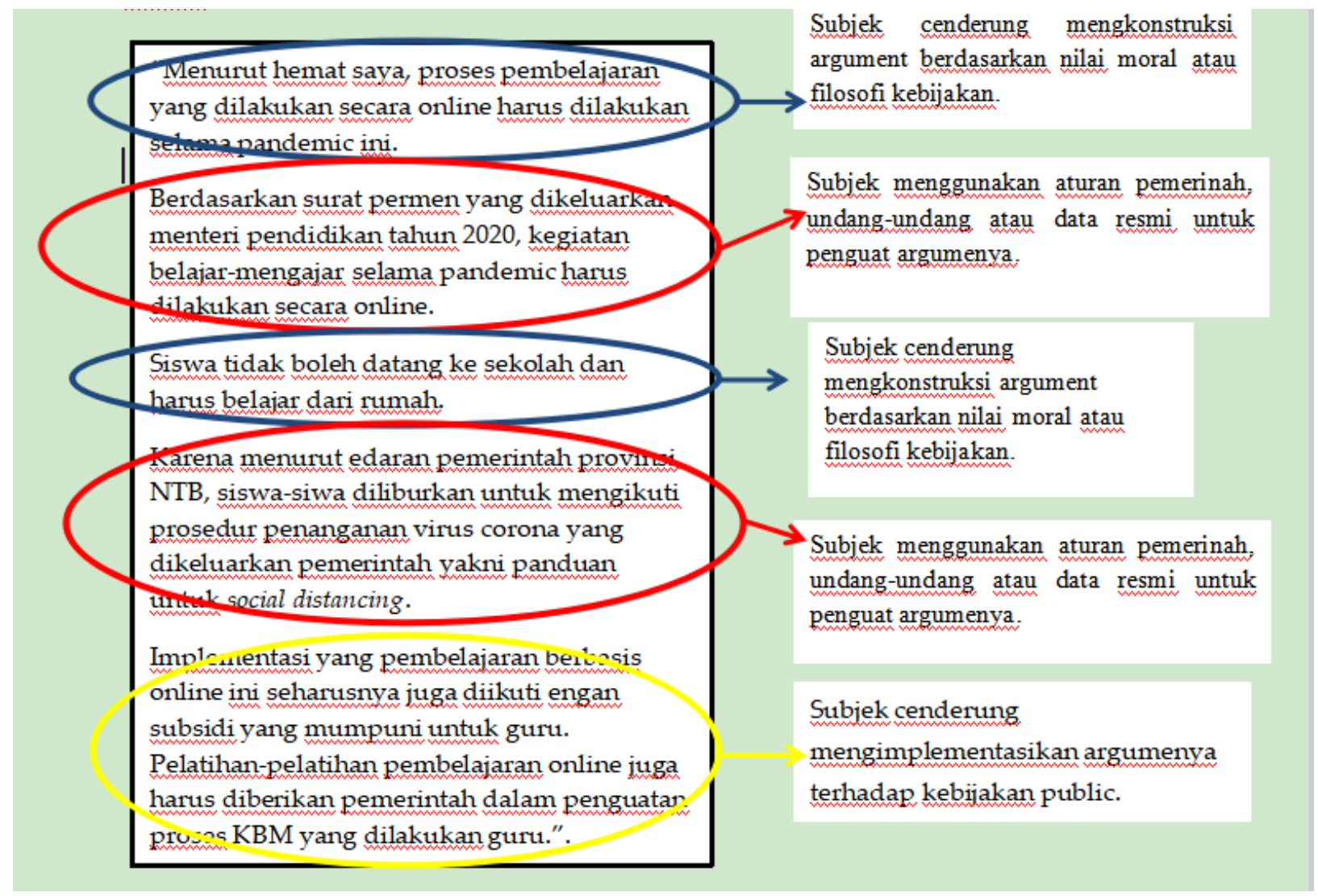

Gambar 4. Struktur Argumentasi Kategori Policy Argument 
Untuk memperjelas perbedaan antara ketiga kategori argumentasi diatas, dapat dilihat dalam table sebagai berikut.

Tabel 1. Perbedaan dari Jenis Argumentasi

\begin{tabular}{|c|c|c|}
\hline No & Jenis Argumentasi & Deskripsi \\
\hline 1 & True-False Argument & $\begin{array}{l}\text { a) Subjek mengkonstruksi argument untuk menunjukan } \\
\text { kebenaran atau kesalahan suatu fakta. } \\
\text { b) Subjek memberikan dukungan-dukungan teoritis } \\
\text { terkait kebenaran fakta yang disampaikan. } \\
\text { c) Subjek meberikan sanggahan terhadap argument } \\
\text { subjek lain untuk memperkuat kebenaran argumenya. }\end{array}$ \\
\hline 2. & Good-Bad Argument & $\begin{array}{l}\text { a) Subjek cenderung mengkonstruksi argument untuk } \\
\text { menunjukkan penggunaan atau implementasi suatu } \\
\text { argument. } \\
\text { b) Menilai kebenaran dan kesalahan argument } \\
\text { berdasarkan tindakan (baik dan buruk). } \\
\text { c) Subjek menyelipkan manfaat dan kebergunaan } \\
\text { implementasi argumenya. }\end{array}$ \\
\hline 3. & Policy Argument & $\begin{array}{l}\text { a) Subjek cenderung mengkonstruksi argument } \\
\text { berdasarkan nilai moral atau filosofi kebijakan. } \\
\text { b) Subjek menggunakan aturan pemerinah, undang- } \\
\text { undang atau data resmi untuk penguat argumenya. } \\
\text { c) Subjek cenderung mengimplementasikan argumenya } \\
\text { terhadap kebijakan public. }\end{array}$ \\
\hline
\end{tabular}

\section{PENUTUP}

Berdasarkan hasil penelitian yang dilakukan dapat disimpulkan beberapa hal sebagai berikut: (1) Jenis argument yang digunakan mahasiswa dapat terbagi menjadi tiga yakni (a) TrueFalse Argument, yakni mahasiswa yang menggunakan argumennya untuk membenarkan atau menyalahkan pernyataan orang lain; (b) Good-Bad Argument, yakni mahasiswa cenderung menggunakan argumenya untuk melihat kebermanfaatan dan implementasi dari pernyataanya untuk menyelesaiakn masalah yang dihadapi; dan (c) PolicyArgument, yakni mahasiswa yang cenderung menggunakan data-data resmi, Undang-Undang atau kebijakan pemerintah untuk memperkuat pendapat yang disampaikan. (2) Argument yang paling sering digunakan oleh mahasiswa adalah argument True-False Argument dimana mahasiswa dalam kelompok ini cenderung membenarkan pernyataanya atau menyanggah pernyataan orang lain dengan teoriteori yang sudah ada dan dianggap benar (valid). (3) Pola argumentasi ketiga jenis memiliki kesamaan yang hampir mirip yakni diawali dengan argumenya, dilanjutkan dengan data pendukung (baik berupa teori, pendapat pribadi, maupun kebijakan pemerintah) dan diakhiri dengan kalimat argumentasi akhir.

\section{DAFTAR PUSTAKA}

Anugrahana, A. (2013). Tinjauan Deskriptif Penerapan Higher Order Thinking dan ProblemBased Learning Pada Mata Kuliah Geometri Berdasarkan Kemampuan Matematika Mahasiswa. Jurnal Pendidikan Dan Pembelajaran Khatulistiwa, 3(2), 142-156.

Boell, S. K., \& Hovorka, D. S. (2019). Writing, Arguing, Contributing - A Cogent 
Argumentation Framework for Identifying, Specifying, and Evaluating Research Contribution. Australasian Journal of Information Systems, 23(1), 1-16. https://doi.org/10.3127/ajis.v23i0.1857

Creswell, J. W. (2012). Educational research: Planning, conducting, and evaluating quantitative and qualitative research. In Educational Research (Vol. 4). https://doi.org/10.1017/CBO9781107415324.004

Davidson, N., \& Major, C. H. (2014). Boundary Crossings: Cooperative Learning, Collaborative Learning, and Problem-Based Learning. Journal on Excellence in College Teaching, 13(5), 43-67.

Dolmans, D. H. J. M., Loyens, S. M. M., Marcq, H., \& Gijbels, D. (2016). Deep and surface learning in problem-based learning: a review of the literature. In Advances in Health Sciences Education (p. 215). https://doi.org/10.1007/s10459-015-9645-6

Eemeren, F. H. Van, Frans, H., \& Garssen, B. (2010). Pondering on Problems of Argumentation: Twenty Essays on Theoretical Issues. In Argumentation Library (Vol. 14, Issue 1, pp. 112115). Springer.

Gavgani, V. Z., Hazrati, H., \& Ghojazadeh, M. (2015). The Efficacy of Digital Case Scenario Versus Paper Case Scenario On Clinical Reasoning in Problem-Based Learning : A Systematic Review and Meta-Analysis. Res Dev Med Educational, 4(1), 17-22. https://doi.org/10.15171/rdme.2015.003

Gustina, \& Miaz, Y. (2019). Peningkatan Aktivitas dan Hasil Belajar Materi Gejala Alam Melalui Pendekatan Saintifik Model Doscovery Learning Metode Diskusi Kelompok di Kelas VI SD Negeri 54 Payakumbuh. Jurnal Basicedu: Research \& Learning in Elementary Education, 3(2), 428-434.

Hendarto, P., \& Adi, B. (2019). Validity of guided inquiry-based modules on digestive system to improve argumentation skill. Jurnal Pendidikan Biologi Indonesia, 5(1), 127-140.

Ijirana, \& Nadjamuddin, L. (2019). Time Series Study of Problem Solving Ability of Tadulako University Students Using Metacognitive Skill Based Learning Model. International Journal of Engineering Pedagogy, 14(21), 227-234.

Indraswati, D. (2018). Efektivitas Model Pembelajaran Kooperatif Tipe Numbered Heads Together ( NHT ) Terhadap : Kompetensi Sikap Siswa , Kompetensi. JOURNAL RESEARCH AND ANAL YSIS : ECONOMY, 1(2), 52-58.

Indraswati, D., Marhayani, D. A., Sutisna, D., Widodo, A., \& Maulyda, M. A. (2020). Critical Thinking Dan Problem Solving Dalam Pembelajaran Ips Untuk Menjawab Tantangan. Sosial Horizon, 7(1), 12-28. https://doi.org/10.31571/sosial.v7i1.1540

Maulyda, A. M., Hidayati, V. R., Erfan, M., Umar, \& Sutisna, D. (2020). Kesalahan Komunikasi Matematis (Tertulis) Siswa Ketika Memahami Soal Cerita. Jurnal Karya Pendidikan Matematika, 7(1), 1-7.

Maulyda, M. A., Annizar, A. M., Hidayati, V. R., \& Mukhlis, M. (2020). Analysis of students ' verbal and written mathematical communication error in solving word problem. Journal of Physics: Conference Series, 1538(012083), 1-12. https://doi.org/10.1088/17426596/1538/1/012083

Maulyda, M. A., \& Hidayati, V. R. (2019). Representasi Matematis Visual Anak Ditinjau dari Bakat Musik. EDU-MAT: Jurnal Pendidikan Matematika, 7(2), 149-158. https://doi.org/10.20527/edumat.v7i2.6855

Mazilu, S. (2017). The Use of Analogy in Pro-Life Argumentation. Journal of Advanced Academics, 12(3), 55-78. 
Myklebust, H., \& Høisæter, S. (2018). Written Argumentation for Different Audiences. A Study of Addressivity and the Uses of Arguments in Argumentative Student Texts. Acta Didactica Norge, 12(3), 10. https://doi.org/10.5617/adno.4727

N, W. D., Reed, C., \& Macagno, F. (2013). Argumentation Schemes. In Cambridge: Cambridge University Press (p. 443). Cambridge University Press.

Nofitasari, A., Yuana, R. A., \& Maryono, D. (2019). The Use of Robomind Application in Problem Based Learning Model to Enhance Student's Understanding in the Conceptual Programming Algorithm. Indonesian Journal of Informatics Education, 1(1), 1-11.

Osborne, J. (2017). Towards a more social pedagogy in science education: the role of argumentation. Journal of Advanced Academics, 7(1), 1-16.

Santoso, B., Putri, D. H., \& Medriati, R. (2020). Upaya Meningkatkan Motivasi Belajar dan Kemampuan Pemecahan Masalah Siswa Melalui Model Problem Based Learning Berbantu Alat Peraga Konsep Gerak Lurus. Jurnal Kumparan Fisika, 3(1), 11-18.

Savchuk, T. N. (2017). Classificaton Schemes of Argumentation in The Humanities Discourse: On the Material of Russian and Belarusian Texts. Journal of Social Studies Education Research, 16(1), 97-108.

Schunk, D. H. (2012). Learning theories: An educational perspective. In Reading (1st ed.). Focus on ExCale.

Siegel, H. (1995). Why Should Educators Care about Argumentation? Informal Logic, 17(2), 159-176. https://doi.org/10.22329/il.v17i2.2405

Sunaringtyas, A. D., Asikin, M., \& Junaedi, I. (2017). The Student's Analysis of Creative Thinking Process in Solving Open Problems Viewed from Wallas Model on Problem Based Learning Model. Unnes Journal of Mathematics Education, 6(3), 287-293. https://doi.org/10.15294/ujme.v6i3.16084

Sutisna, D., Indraswati, D., \& Sobri, M. (2019). Keteladanan Guru sebagai Sarana Penerapan Pendidikan Karakter Siswa. Jurnal Pendidikan Dasar Indonesia, 4(2), 29-33. https://doi.org/http://dx.doi.org/10.26737/jpdi.v4i2.1236

Walton, D. (2018). Witness Impeachment in Cross-Examination Using AD Hominem Argumentation. Studies in Logic, 55(68), 93-114. https://doi.org/10.2478/slgr-2018-0030

Widodo, A., Husniati, H., Indraswati, D., Rahmatih, A. N., \& Novitasari, S. (2020). Prestasi belajar mahasiswa PGSD pada mata kuliah pengantar pendidikan ditinjau dari segi minat baca. Jurnal Bidang Pendidikan Dasar, 4(1), 26-36. https://doi.org/https://doi.org/10.21067/jbpd.v4i1.3808 